\title{
Contribution of Building Façades to Attractive Streetscapes: Study of Two Main Streets in Kuala Lumpur City
}

\author{
Amir Hossein Askari ${ }^{1 *}$, Soha Soltani ${ }^{2}$ \\ ${ }^{I}$ Department of Art and Architecture, Shiraz Branch, Islamic Azad University, Shiraz, Iran \\ ${ }^{2}$ Department of Landscape Architecture, University Putra Malaysia, Malaysia \\ *amir1360.askari@gmail.com
}

Received : 26 August 2017 Final Version Received: 2 April 2018

\begin{abstract}
Building facades contribute to attractive urban streetscapes. In between, physical elements and visual qualities of building façades play the most important role. This study seeks to identify the impact of building facades on creating attractive streetscapes in the city of Kuala Lumpur. In achieving this, a self-administered questionnaire survey was conducted to gather peoples' evaluation of building facades in Kuala Lumpur where combination of modern and traditional architecture creates worth-study urban landscapes. The researcher randomly surveyed 330 respondents, 18 to 50 years old, from the passers-by who just visit the area and those who reside and work there, using the time interval sampling method. The results demonstrate that consistency of colors and details of building facades, simplicity, unity, conformity of store lots in a single building block, large windows, transparency of the function of buildings, and display items of store-fronts determine visual richness of streetscapes in the study areas. The findings contribute to visual identity of cities through creating attractive streetscapes.
\end{abstract}

Keywords: Streetscapes, Building façades, Physical elements.

\section{INTRODUCTION}

Evaluation of a streetscape mainly depends on people's perception of building facades. Physical elements and visual characteristics of building facades play a significant role in creating attractive streetscapes. Scholars such as, Nasar et al (2005); Myers (2007); Akalin et al (2009); Askari and Dola (2009), stressed the role of building facades in forming streetscapes. Most of the current studies rely on the Western contexts and have no significant role in improving streetscapes in the Southeast Asian urban contexts like Kuala Lumpur (Oranratmanee \& Sachakul, 2014). City Hall Kuala Lumpur (2008) emphasized the lack of streetscape consistency along main streets and broad visual linkages in the City Center. The new buildings emerged create monotonous urban streetscapes in most areas of Kuala Lumpur (Wan Ismail \& Shamsuddin, 2005). Most of new building facade designs contradict their contexts that this brings about an urban threat to traditional streetscapes in the city (Ja'afar et al., 2012). Study of role of building facades in configuring streetscapes in Kuala Lumpur has hitherto remained scant in most areas. Hence, the main objective of this study is to identify the impact of building facades on creating attractive streetscapes in the city of Kuala Lumpur. The main questions addressed are "How important are building facades in creating attractive streetscapes?" and "What characteristics and physical elements of building façades create attractive streetscapes?" The first section analyzes the relevant issues concerning the role of building facades in creating streetscapes. The second section shows method applied, data collection procedure, findings, and conclusion.

\section{LOCATION AND SITE PLANNING}

\subsection{STREETS AND URBAN CONTEXTS}

Various studies on the design of the built environment have given a due attention to a street as a public space (Lynch, 1960; Moughtin, 2003). The definitions of a street vary in terms of scope and research perspectives. In Jacobs' view (1961), before giving a suitable definition of a street, the sociological characters and physical elements, which form it, have to be first understood. Lynch (1960), in his perspective 
towards urban forms, stated that a street is a path enlivened by a series of nodes where other paths meet it or where activities are strengthened (Shamsuddin et al., 2012). This attitude introduces streets as dynamic spaces with the sense of movement (Krier, 1977; Carmona et al., 2003). In light of urban design, a street is one of the main elements besides squares and buildings in making the face of cities (Moughtin, 2003). Streets vary from length, cross-section, shape, character, function, and meaning. Streets are definable in two ways: vertically, which has to do with the height of buildings or walls or trees and horizontally, which concerns the length of and spacing between whatever defines it. Regarding the definition of a street by the previous authors and according to what refers to a street, in most areas of Kuala Lumpur, spaces tally with the definitions of roads (Moughtin, 2003). In the current study, definition of a street is based on the effect of physical elements on its urban landscape. Streets, as significant places in many aspects, are more functional in their characters compared to squares (Ujang, 2008). They play an important role in shaping the quality and characters of urban areas (Krier, 1977). Traditionally, an urban street unites three physical roles: a circulation route, a public space, and a building frontage (Tucker et al., 2004); meanwhile, according to Gehl (2007), streets play three main functions: meeting places, market places, and connection spaces.

The earliest streets in Kuala Lumpur are the urban elements that play an important role in morphological town developments. This shows how streets in Kuala Lumpur characterize urban landscapes of cities. Traditional streets are narrower than modern ones because transportations in the past often relied on rivers, bicycle, trishaws, rickshaws, and bullock carts; thus, did not need broad streets (Shamsuddin, 2011). In traditional streets, five-foot sidewalks play the same role as pedestrians do in current modern streets. Jalan Tuanku Abdul Rahman, as a main traditional street, is a part of the early nexus of Kuala Lumpur in 1859, formerly known as Batu Road in the sixties, associated with Indian Muslim, Indian, and Malay communities. The street has maintained the features of a typically traditional one due to the kinds of buildings and the nature of social activities occurring there. Unlike the shopping malls of newer commercial centers, the building frontages are not closed and introverted. Social activities in Jalan Tuanku Abdul Rahman are controlled and the sidewalks are devoid of hawkers (Shamsuddin, 2011). Overall, streets in Kuala Lumpur serve a functional purpose and most people in urban areas live on streets and regularly pass through them in their everyday life (Shamsuddin, 1997).

\subsection{STREETSCAPE}

In urban design, spatial or unique qualities of a place reflect its visual urban landscape (Greene, 1992). Urban identity relates to the characteristics that make an environment, such as a street, distinct from others (Lynch, 1981; Shamsuddin, 2011). A streetscape plays an important role in defining characteristics of urban areas (Nasar, 1990; Shamsuddin, 2011). Analysis of a streetscape is essentially individuals' interpretations of what appears to be visually significant (Tucker et al., 2004). Physical elements of an environment play an important role in constructing its identity (Proshansky, 1978). Distinctiveness of physical elements and observers' perceptions of visual appearance are vital components of place image making process (Proshansky, 1978). This pinpoints the important role of observers in making streetscapes. People easily recognize and remember the distinctive physical elements such as building facades. Building facades are the important urban elements that contribute to streetscapes. Size, height, shape, color, skyline, movement, surface, quality (texture), signs, edge, designs, materials, condition (upkeep and landscaping), arrangement of building facades, openness, spaciousness, enclosure, and territorial definition are attributes of physical elements of streets (Shamsuddin, 2011). Therefore, a streetscape that reflects its urban identity mainly relates to interplay between users and constituting physical elements.

Complexity of a streetscape visually expressed is an important determinant of its characters (Tucker et al., 2004), which its level shows whether users consider it attractive, memorable or distinctive (Berlyne, 1974; Imamoglu, 2000; Stamps III, 2004). The perceived number of elements within a streetscape and "noticeable differences" between them indicate visual complexity (Rapoport, 1990:269). The way users feel the differences in their memories while perceiving a streetscape specifies the extent to which the visual elements and qualities of such a streetscape or their combination might be felt monotonous, surprising or familiar (Tucker et al., 2004). This shows how the differences in observers' perceptions of physical elements underpin their evaluations of streetscapes.

\subsection{EVALUATION OF STREETSCAPES}

Evaluation of a place is underscored with perception of its constituting elements. People's 
evaluation of an environment usually relies on physical appearances of the place, which is often exact and precise (Rapoport, 1980; Nasar et al., 2005). Evaluation of architectural quality of the built environment partially relies on physical features of buildings (Gifford et al., 2000; Brown and Gifford, 2001). Evaluation of urban landscape depends on observers' reasoned and emotional responses, which are respectively consequences of cognitive and affective evaluations (Baloglu and McCleary, 1999; Beerli and Martı'n, 2004). Cognitive evaluation is related to the knowledge and belief about the image and affective appraisal addresses feelings about it (Beerli and Martı'n, 2004). Visitors' evaluations of a place might change according to personal differences (Naoi et al., 2006) or cultural aspects (Rapoport, 1980).

Employing different methods and perspectives, numerous scholars addressed evaluation of building facades. Mehta (2007) evaluated how people respond to environmental quality of neighborhood commercial streets via behavioral perceptions. In a similar study, Mehta and Bosson (2009) conducted a study on main streets in North America employing a visual analysis technique to determine users' evaluation of qualities. Gjerde (2011) bridged between public and experts' visual evaluation of urban streetscapes. The findings showed that professionals, such as architects, designers, and landscape designers, reveal similar opinions to laymen when it comes to evaluation of physical elements of urban streetscapes. The difference emerges when professionals find out flaw and dishonesty in architectural conventions, while laymen express a neutral opinion about that. Nagaoka et al. (2013) in their study conducted in Chofu area in Shimonoseki evaluated streetscape based on actual photographs using a traditional semantic differential method. The results revealed that designers should consider color guidelines to harmonize the color schemes in urban streetscapes. With a deeper and more holistic viewpoint than others, Li et al. (2013) used Breiman's random forests method to study the impact of physical factors on evaluation of streetscapes and their effective operation in Japan and China. The results of their study demonstrated that the physical factors affecting streetscapes vary from country to country. Yet, the three main factors influencing evaluations of streetscapes were comfort, beauty, and activity.

\subsection{BUILDING FACADES}

Urban façades that delineate transition between public and private domains seem vital if continuity of the façades helps to define urban spaces as the container of urban life (Gharai \& Shokouhi, 2006). Form of the buildings should appear as a surface rather than as a mass. Moughtin et al. (1995) concurred that buildings with strong three-dimensional forms create masses that dominate urban scenes in which urban spaces lose significance. This is supported by Ardalan \& Bakhtiar (1975) that harmonious rhythm of articulated building facades plays a considerable role in improving visual identity of urban spaces. In light of building facades, the lower facades create an important linkage between scales, buildings, and people. For the buildings regarded a unified entity, the lower facades should own a brilliant and friendly design (Gehl et al., 2008). As the horizontal lines lead the eye, ground floor height is essential to pedestrians. Designing continuous cornices, applying similar techniques, and architectural elements create a horizontal line above the ground floor. Rhythm is another important factor that modulates building façades in an urban context (Gharai \& Shokouhi, 2006). It is a mysterious fact of esthetic experience that is formed by groups of elements to create emphasis, interval, accent, and /or direction (Carmona et al., 2003). To avoid monotony, contrast and variety are two essential factors in achieving interesting rhythms (Moughtin, 2003).

In Malaysian cities, one of the important urban elements that influence building façades evaluation is five-foot walkway. However, new buildings in the old areas do not emphasize this character. Yet, some buildings have changed the appearance by creating a different height. This design exposes pedestrians to elements; scenario becomes worse when new buildings do not offer five-foot walkways (Ja'afar, 2006; Ja'afar et al., 2012). In Kuala Lumpur, early buildings in traditional parts of cities are two-story shophouses, typical buildings linked to each other in a row with five-foot walkways, which house retail activities on the ground level and the residence on the upper level. These five-foot walkways both act like shelters that protect people from rain and sunlight and link them to streets by increasing the sense of enclosure. In modern streets in Kuala Lumpur, width of streets and sidewalks between streets and buildings lower the sense of enclosure (Shamsuddin, 2011). Critical review of literature points out that physical elements and characteristics and visual qualities of building facades important for evaluating attractive streetscapes, are considered analysis units of the current study.

\section{METHOD OF STUDY}

\subsection{QUANTITATIVE APPROACH}


This study employed a self-administered questionnaire survey that assisted in measuring people's evaluations of role of building façades in forming attractive streetscapes. A selfadministrated questionnaire includes questions answered by respondents (Fink, 2003). This kind of survey has advantages over other types of data collection instruments. In particular, it is not costly and time-consuming to gather information. Ujang \& Dola (2012); Shamsuddin \& Ujang, (2008); Mehta \& Bosson (2009); Ujang \& Shamsuddin (2012); Askari et al. (2013) accentuated suitability of quantitative approach using a questionnaire survey in similar studies. A total number of 330 respondents participated in the surveys comprised passersby, shoppers, workers, office workers, storekeepers, storeowners, and residents with Malaysian identity familiar with the study areas. Shamsuddin (2011) stated that people's evaluations of physical elements of the environment depend on visual images that the familiarity and memories of the place create in their minds. Therefore, the difference in tourists' evaluations of the environment with that of locals limited the respondents to Malaysians with a relative familiarity with the study areas, who aged 18 to 50 years old and above. The equal ratio of male and female eliminated the gender-biased effect on reliability of the results. According to the observation technique supported by Ja'afar \& Usman (2009), the researcher assigned a group of trained students of architectural studies from the Faculty of Design and Architecture at University Putra Malaysia to be stationed in the major entrances of the study areas.

Similar to studies by Johnson \& Christensen (2011) and Ja'afar \& Usman (2009), this study applied a time-interval sampling method in which the researcher is involved in checking an event in specified time-intervals. Using this method, the researcher randomly asked passersby to participate in the survey every 10 minutes in the study areas. Data collection was conducted in October and November 2013 and, on average for each street, the researcher succeeded in convincing the respondents to fill out 30 questionnaires a day. The response ratio was five to one, meaning that out of five people, one was eager to cooperate and answer the questions. Data were gathered on weekdays, weekends, and public holidays in the morning, afternoon, and evening. The questionnaire included the questions that explored people's evaluations of role of physical elements of building facades in creating attractive streetscapes using five scales of strongly agree, agree, not sure, disagree, and strongly disagree. First, the respondents were asked to evaluate the role of five-foot walkways, physical attributes of awnings, number of shop lots, design of building facades and frontages, and physical elements and attributes of building facades in creating attractive streetscapes in the selected areas. Second, the respondents rated building facades of the two selected streets based on degree of attractiveness of design elements. All the questions were closed-ended to give a clear status to the participants in declaring their evaluations. The role of physical elements and attributes of building facades in creating attractive streetscapes was determined using Pearson Correlation Analysis Test. Moreover, the most attractive building facades of the streets were ranked according to their frequency and percent. According to Ryan (2005) and Akalin et al. (2009), efficiency of Cronbach's Alpha should be more than 0.70 . The results showed that Cronbach's Alpha was 0.794 and 0.808 for building facades of the study areas.

\subsection{PILOT STUDY}

Pilot study is a way to check an instrument, such as a questionnaire, before it is made final (Fink, 2003). Hoinville \& Jowell (1978) stated that pilot study is a way to redefine wording and ordering and to prune the questionnaire so that it becomes less lengthy. One outcome of a good pilot study is finding out the time taken by participants to complete a questionnaire (Fowler, 1988). According to De Vaus (2002), this study tried to consider steps such as flow, timing, and participants' interest in pilot study stage. The researcher repeated the pilot study four times in October 2013 to ensure that the questions would rigorously convey opinions. The number of respondents was 60 , i.e. the team collected 30 questionnaires for each street, $20 \%$ of the total number in the final survey. The pilot study helped to replace unclear terms with easy-tounderstand ones. It showed that some locals could not understand most of English words used. Hence, a Malay version was prepared with the aid of lecturers and students of the Faculty of Design and Architecture at University Putra Malaysia too. In brief, the whole process of pilot study supported internal reliability of the questionnaire to ensure that all the questions relate to the objective of the study.

\subsection{THE STUDY AREAS}

The researcher listed and compared potential streets in the heart of Kuala Lumpur City according to their physical elements and visual qualities. Among all streets, two main streets that comprise both local and international urban landscapes of the city were selected: a) Jalan 
Bukit Bintang (JBB) and b) Jalan Tuanku Abdul Rahman (JTAR). The two selected streets lie in the main commercial districts with diverse economic activities. They are identifiable as the main streets and well known for popular shopping areas receiving the highest concentration of pedestrians, shoppers, and tourists (City Hall Kuala Lumpur, 2008 cited in Ujang, 2012). JBB (Figure 1) is within Bukit Bintang shopping district stretching from Jalan Pudu to Jalan Raja Chulan and intersects with Jalan Sultan Ismail. It was named Kuala Lumpur Golden Triangle in the early 1980s, a shopping heaven with a profusion of exclusive and branded retail stores, restaurants, hotels, and active nightlife. According to Ujang (2008), JBB comprises a wide range of retail and entertainment facilities and a growing number of offices. The street is characterized by its modern and international image. Visited by foreign tourists, Bintang Walk, approximately one kilometer of pedestrian walkway where hotels stand alongside modern shopping malls, vibrates the street. The monorail transport links the area with other places and supports as an access point to local shoppers, tourists, and visitors.

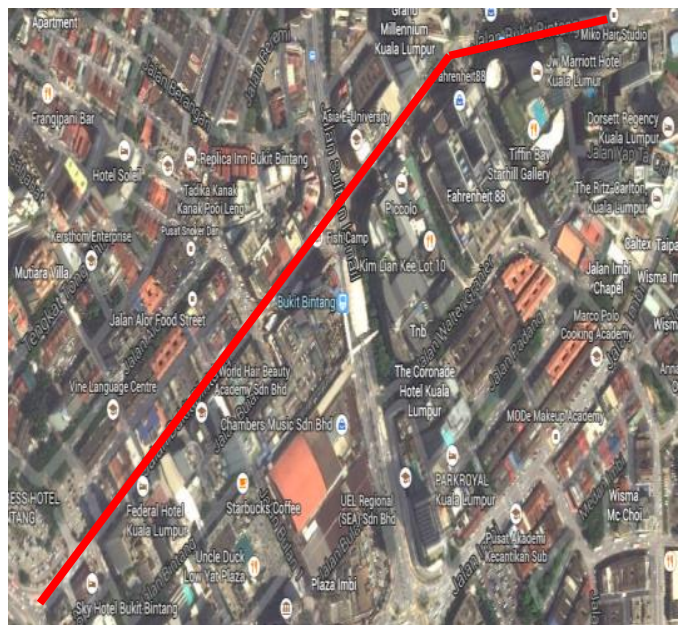

Figure 1: Bukit Bintang Street

Source: Imagery @ 2014 Digital Globe, Map data@2014 Google.

Tuanku Abdul Rahman Street (Figure 2) lies within Tuanku Abdul Rahman shopping district expanding from Sultan Ismail Street to Raja Laut Street. The street is one of the traditional streets with salient socio-cultural values and historical importance in the heart of Kuala Lumpur City. In the historical zone of the city, it is the first high street that overflows with shopping activities. There are a significant number of meanings attached to this street due to its sizable number of established chain stores specialized in textile trades. Social activities, shophouses, and shopping malls along the street support a high absorption of shoppers, visitors, and pedestrians. The street lies in the area designated for urban regeneration program (City Hall Kuala Lumpur, 2008). Despite new and modern shopping malls, the traditional shophouses, old departmental stores, arcades, and street vendors are still the main urban constituents strengthening characters of the street. The salience of its characteristics depends on the architecture of two-story traditional shophouses with five-foot walkways along the street.

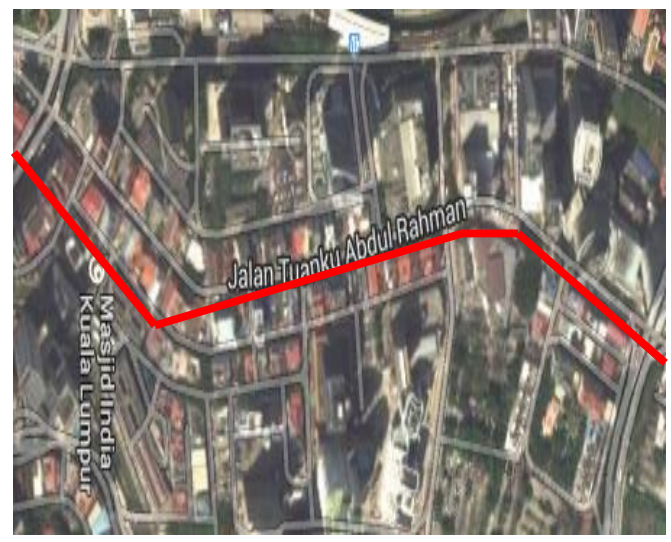

Figure 2: Tuanku Abdul Rahman Street Source: Imagery @ 2014 Digital Globe, Map data@2014 Google.

\section{FINDINGS AND DISCUSSION}

\subsection{ROLE OF BUILDING FACADES IN CREATING ATTRACTIVE STREETSCAPES}

Table 1 shows that building facades obtain $($ Mean $=3.6791$, Std. $=0.57676)$ based on people's evaluation of Bukit Bintang Street and (Mean= 3.6285, Std. $=0.55097)$ for building facades of Tunku Abdul Rahman Street. People asserted that building facades of Bukit Bintang Street play a more important role in creating attractive streetscapes than those of Tunku Abdul Rahman Street.

Table 1: Building Facades Importance

\begin{tabular}{|l|l|l|l|}
\hline Variables & Number & Mean & $\begin{array}{l}\text { Std. } \\
\text { Deviation }\end{array}$ \\
\hline $\begin{array}{l}\text { Bukit } \\
\text { Bintang } \\
\text { Street: } \\
\text { Building } \\
\text { Facades }\end{array}$ & 185 & 3.6791 & 0.57676 \\
\hline $\begin{array}{l}\text { Tunku } \\
\text { Abdul } \\
\text { Rahman } \\
\text { Street: } \\
\text { Building } \\
\text { Facades }\end{array}$ & 185 & 3.6285 & 0.55097 \\
\hline
\end{tabular}


Pearson Correlation Test, shown in Table 2, indicates that there is a correlation between building facades $(r=0.494, p<0.01)$ and Bukit Bintang streetscapes. The stores with large windows, clarity of the building functions, variety of the buildings, and display items of the store-fronts contribute to attractive streetscapes. The result shows that various designs of building facades, welcoming entrances, interesting views created with shadows, cleanliness of building frontages, and colorful and detailed building facades play an important role in forming streetscapes as well.

Table 2: Correlation between Building Facades and Bukit Bintang Streetscapes

\begin{tabular}{llc}
\hline Variable & & $\begin{array}{c}\text { Building } \\
\text { Facades }\end{array}$ \\
\hline Streetscape & Pearson & $0.494(* *)$ \\
& Correlation & \\
& Sig. (2-tailed) & 0.000 \\
& $\mathrm{~N}$ & 185 \\
\hline
\end{tabular}

Results of the Pearson Test, shown in Table 3, show that there is a correlation between building facades $(\mathrm{r}=0.566, \mathrm{p}<0.01)$ and Tunku Abdul Rahman streetscapes. The stores with large windows, clarity of the building functions, variety of the buildings and shophouses, and display items of the store-fronts are the factors that form attractive streetscapes. Consistent designs of building facades, proper colors, materials, and lines having esthetic values etch memorable streetscapes on the users' minds. The results show that five-foot corridors, variety of colorful awnings, various designs of shophouses, welcoming entrances of the buildings, interesting views created with shadows, cleanliness of building frontages, and colorful and detailed building facades contribute to streetscapes as well.

Table 3: Correlation between Building Facades and Tunku Abdul Rahman Streetscapes

\begin{tabular}{llc}
\hline Variable & & $\begin{array}{c}\text { Building } \\
\text { Facades }\end{array}$ \\
\hline Streetscape & Pearson & $0.566(* *)$ \\
& Correlation & \\
& Sig. (2-tailed) & 0.000 \\
& $\mathrm{~N}$ & 185 \\
\hline
\end{tabular}

In a nutshell, five-foot walkways, consistency between physical elements, ornate historical building facades consistent in shape and dimension, and juxtaposition of modern and historical building facades, such as Pawagam Coliseum, of Tunku Abdul Rahman Street create more attractive streetscapes than those of Bukit Bintang Street. Crowdedness of design of facades, inconsistency between designs of old Shophouses, and newly built facades cause a visual interruption and impose a negative impact on Bukit Bintang streetscapes.

\subsection{BUILDING FACADES CONTRIBUTION TO BUKIT BINTANG AND TUNKU ABDUL RAHMAN STREETSCAPES}

Figures 3 and 4 respectively portray the location of interesting building facades of Bukit Bintang and Tunku Abdul Rahman Streets. Table 4 shows attractive facades that form attractive urban landscapes of Bukit Bintang and Tunku Abdul Rahman Streets.

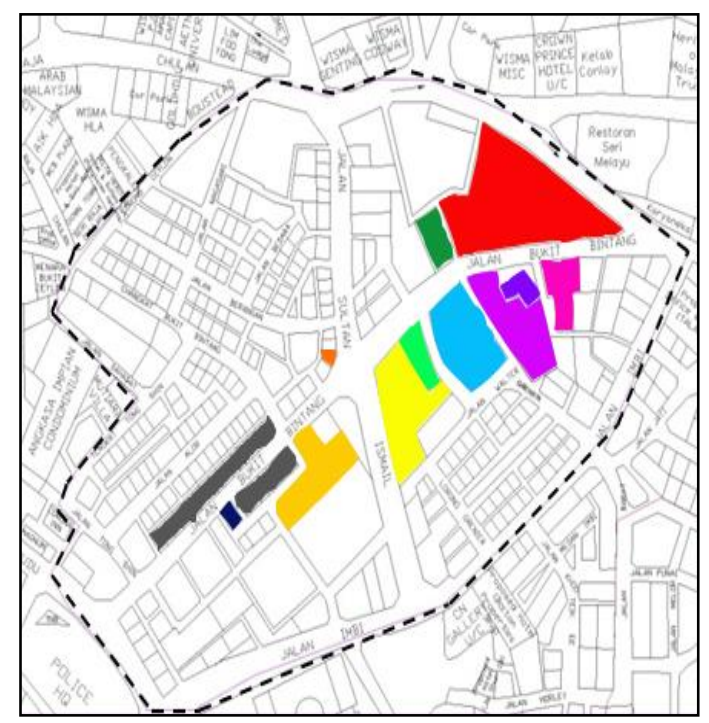

Figure 3: Bukit Bintang Street, from Jalan Tun Razak to Pavilion Source: DBKL Map

Pavilion

Starhill Gallery

Sephora

Farenhaite

Hotel Millinum

Al Amar Café

Lot 10

McDonald

Cimb Bank

Bukit Bintang Plaza

Low rise shop houses

Louis Vuitton shop 


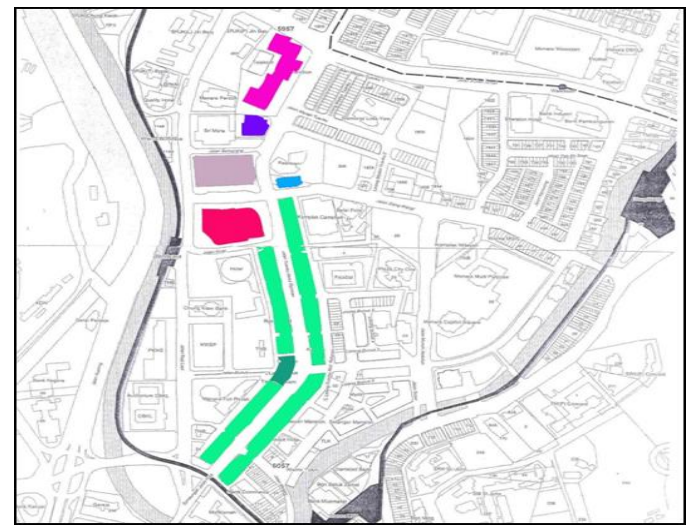

Figure 4: Tunku Abdul Rahman Street Source: DBKL Map

Maju Junction
Sogo
Premiera Hotel
Pertama Complex
City Bazar
Pawagam Coliseum
Low rise Shop House

Table 4: Attractive Building Facades of Bukit Bintang and Tunku Abdul Rahman Streets

\begin{tabular}{lll}
\hline $\begin{array}{l}\text { Building Facades of } \\
\text { Bukit Bintang Street }\end{array}$ & $\begin{array}{l}\text { Frequency } \\
\text { Very much } \\
\text { attractive }\end{array}$ & Percent \\
\hline Pavilion & 40 & 25.32 \\
Sephora & 30 & 19 \\
Starhill & 25 & 15.82 \\
B.B Plaza & 15 & 14.24 \\
Lot 10 & 10 & 6.32 \\
CIMB & 10 & 6.32 \\
Shophouses & 10 & 6.32 \\
\hline Building Facades of & Frequency & Percent \\
Tunku Abdul & Very much & \\
Rahman Street & attractive & \\
\hline Shophouses & 90 & 48.64 \\
Sogo & 45 & 24.32 \\
Maju Junction & 25 & 13.51 \\
Pertama Complex & 12 & 6.49 \\
Pawangam Coliseum & 12 & 6.49 \\
Premiera Hotel & 2 & 1.08 \\
& &
\end{tabular}

Source: Field Survey, 2013

Table 4 indicates that Pavilion (Frequency $=40$, Percent $=25.32)$, Sephora $($ Frequency $=30$, Percent $=19$ ), and StarHill (Frequency $=25$, Percent $=15.82$ ) are the modern buildings that create memorable urban landscapes of Bukit Bintang Street. People stated that shophouses do not strongly contribute to creating strong streetscapes. The reason might be that either traditional shophouses have stigmatized the modern style of this street or combination of traditional urban elements, such as shophouses, and flamboyant modern buildings has created a chaotic urban juxtaposition. Most probably, this chaos has decreased the visual continuity of this street. In more details, the results demonstrate that people prefer to have a continuous combination of modern buildings rather than combination of both traditional and modern ones. The building facades that most contribute to Bukit Bintang streetscapes are shown in Figures 5 to 10 .

Moreover, the results show that shophouses $($ Frequency $=90, \quad$ Percent $=$ 48.64 $), \quad$ Sogo $($ Frequency $=45$, Percent $=24.32)$, and Maju Junction $($ Frequency $=25$, Percent $=13.51$ ) are the buildings that create memorable urban landscapes of Tunku Abdul Rahman Street. People's opinions demonstrate that traditional shophouses, as the core elements of urban settings in Kuala Lumpur, strongly contribute to creating attractive streetscapes. In fact, shophouses have been one of the main constituting elements throughout the history of the street. Unlike Bukit Bintang Street, the results justify that visually pleasant combination of traditional buildings, such as shophouses and modern ones such as Sogo and Maju Junction, creates memorable streetscapes in the users' minds. The building facades that most contribute to Tunku Abdul Rahman streetscapes are shown in Figures 11 to 16.

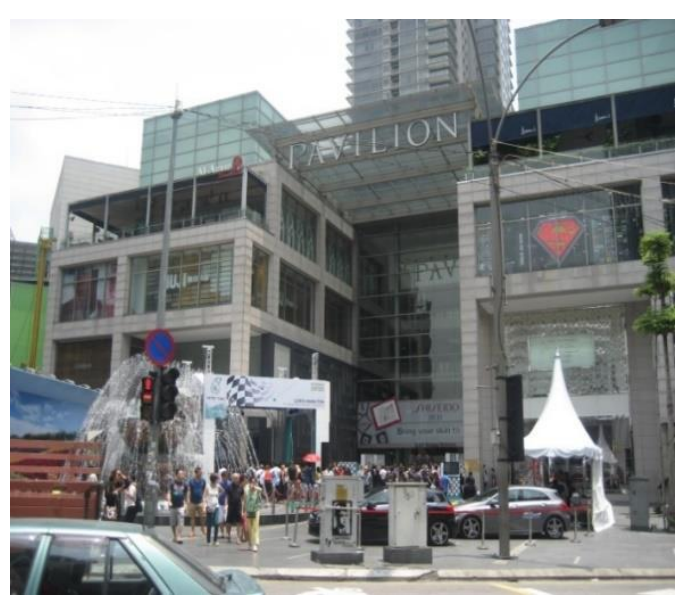

Figure 5: View of Pavilion, Bukit Bintang St. Source: Author, 2013. 


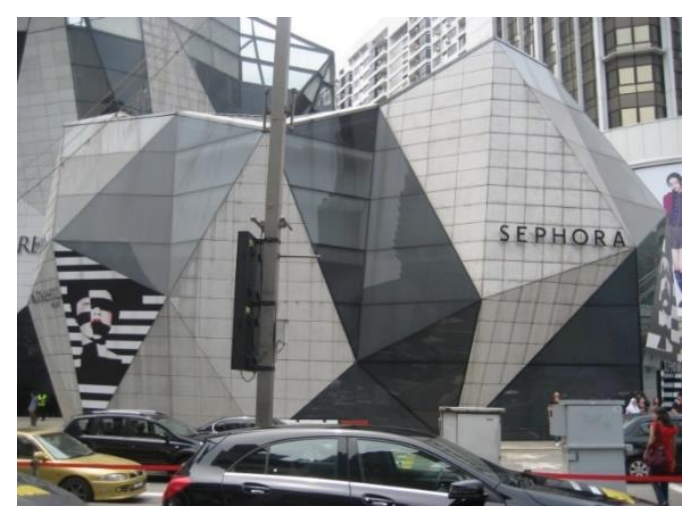

Figure 6: View of Sephora, Bukit Bintang St. Source: Author, 2013.

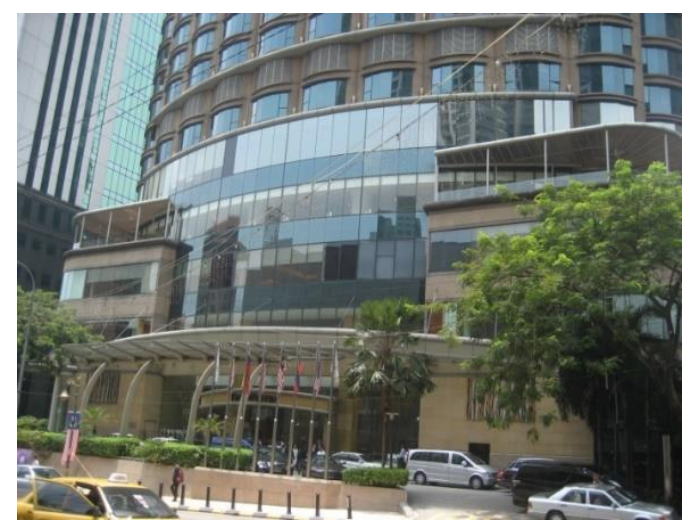

Figure 7: View of Starhill Gallery, Bukit Bintang St.

Source: Author, 2013.

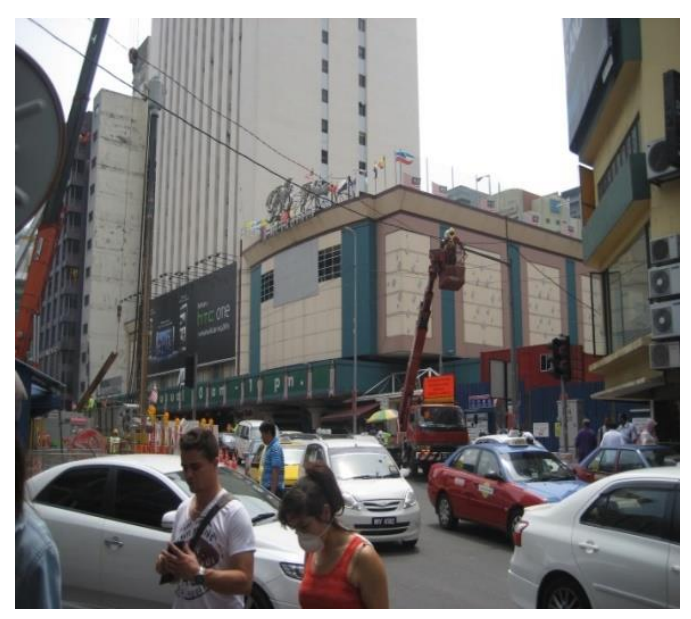

Figure 8: View of BB Plaza, Bukit Bintang St. Source: Author, 2013.

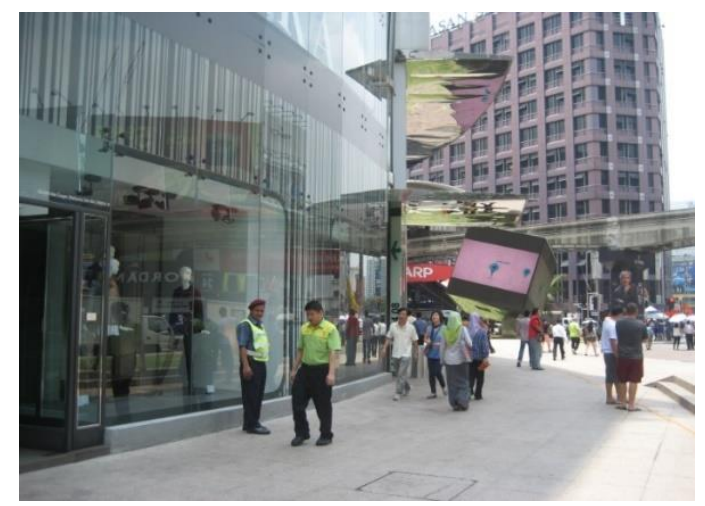

Figure 9: View of the entrance of Lot 10, Bukit Bintang St.

Source: Author, 2013.

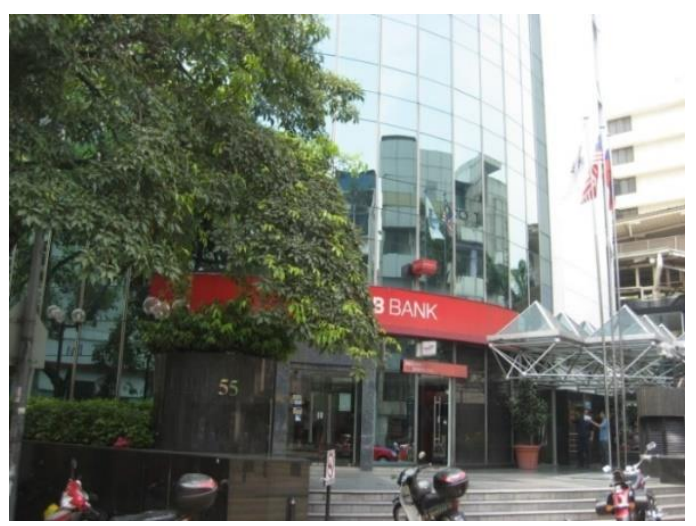

Figure 10: View of CIMB Bank, Bukit Bintang St.

Source: Author, 2013.

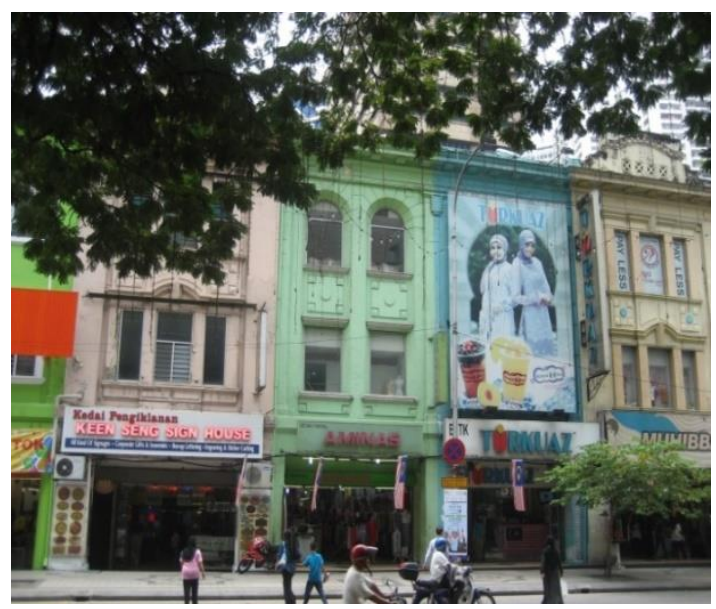

Figure 11: View of shophouses, Tunku Abdul Rahman St.

Source: Author, 2013 


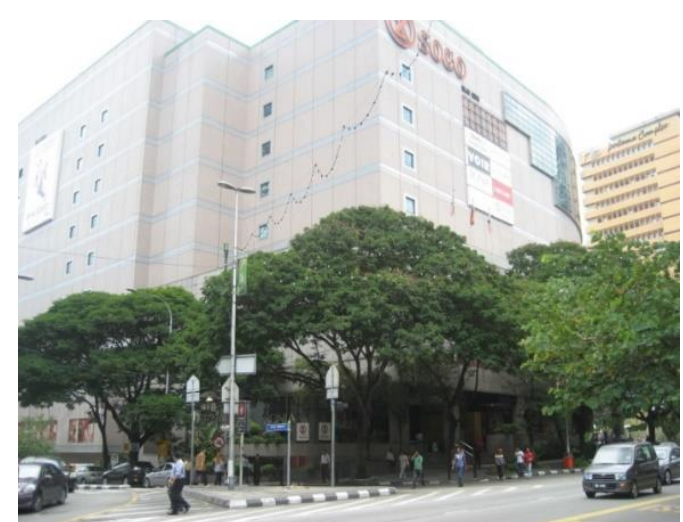

Figure 12: View of SOGO, Tunku Abdul Rahman St.

Source: Author, 2013.

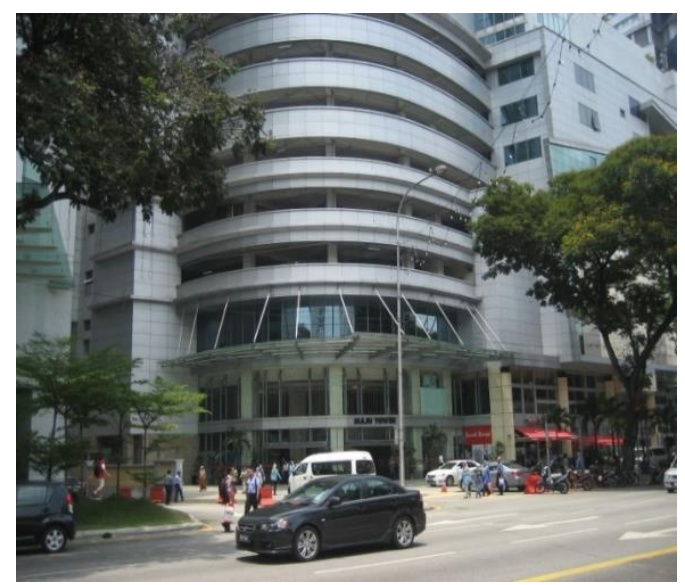

Figure 13: Maju Junction, Tunku Abdul Rahman St.

Source: Author, 2013

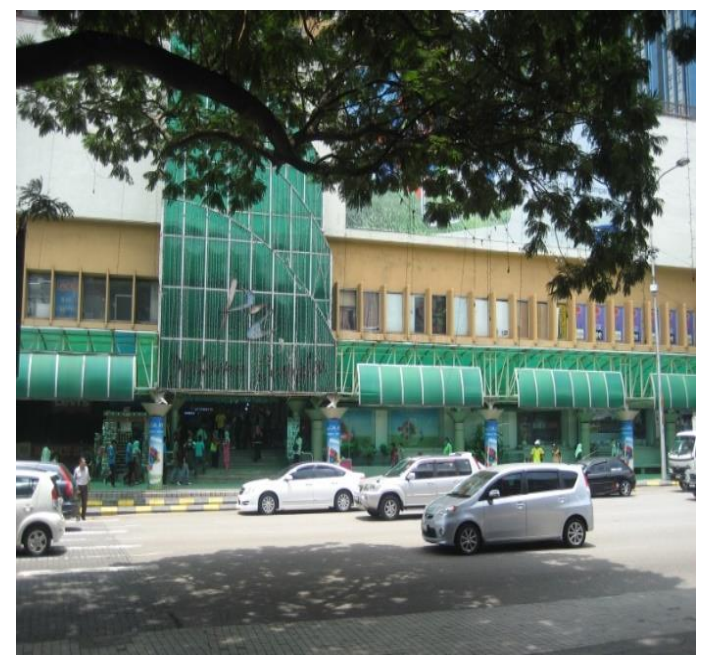

Figure 14: View of Pertama Complex, Tunku Abdul Rahman St.

Source: Author, 2013.

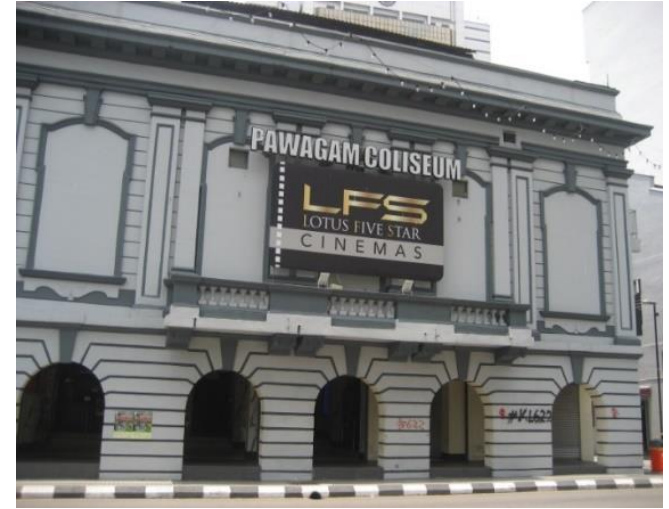

Figure 15: View of Pawagam Coliseum, Tunku Abdul Rahman St.

Source: Author, 2013.

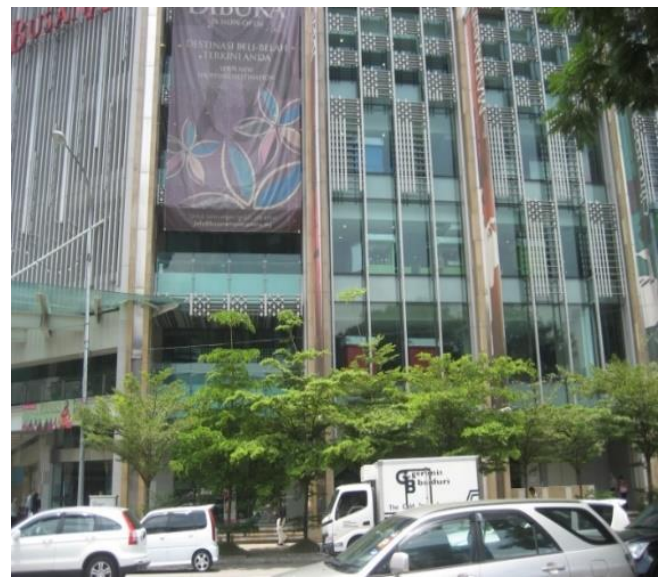

Figure 16: View of Premiera Hotel, Tunku Abdul Rahman St.

Source: Author, 2013.

\section{CONCLUSION}

Building facades play an important role in creating attractive streetscapes in Kuala Lumpur City. Consistency of colors, details, and composition of physical elements of building facades determine the visual richness of a streetscape. Five-foot walkways and variety of awnings with consistent colors attached to building facades create memorable streetscapes in Kuala Lumpur. Simplicity, unity, consistency, and conformity of store lots in a single building block create distinctive streetscapes. Large windows of stores, clarity in seeing function of buildings from outside, and display items of the store-fronts maximize transparency and create distinctive streetscapes. Architectural style, history of a street, and commensurate juxtaposition of modern and traditional building facades influence users' evaluations of streetscapes. An attractive streetscape is memorable, recognizable, symbolic, and fulfilling and arouses sense of attachment and pride to its context. Overall, findings present design-centric suggestions for future 
developments of streetscapes in Kuala Lumpur. The suggestions assist urban designers, architects, landscape architects, town planners, and policy makers in complying with the vision of City Hall Kuala Lumpur in improving visual urban design and landscape of major roads and streets in the city. The current study suggests that future studies identify the impact of ornament, details, motifs, and architectural styles on streetscapes in Kuala Lumpur. Moreover, it suggests a study on the role of spatial arrangement of physical elements in generating images of cities.

\section{REFERENCES}

Akalin, A., Yildirim, K., Wilson, CH., \& Kilicoglu, O. (2009). Architecture and Engineering Students' Evaluations of House Façades: Preference, Complexity and Impressiveness. Journal of Environmental Psychology, 29(1), 124132.

Ardalan, N., \& Bakhtiar, L. (1975). The Sense of Unity: The Sufi Tradition in Persian Architecture. Chicago, IL: Chicago University Press.

Askari, A. H., \& Dola, K. B. (2009). Influence of Building Façade Visual Elements on Its Historical Image: Case of Kuala Lumpur City, Malaysia. Journal of Design and Built Environment, 5(1), 49-59.

Askari, A. H., Dola, K. B. \& Soltani, S. (2013). An evaluation of the elements and elements of historical building façades in the context of Malaysia. Journal of Urban Design International, 19(2) 113-124.

Berlyne, D. (1974). Studies in the New Experimental Aesthetics. New York: Wiley.

Baloglu, S., \& McCleary, K. (1999). A Model of Destination Image Formation. Annals of Tourism Research, 26(4): 868-897.

Beerli, A., \& Martín, J. D. (2004). Factors influencing destination image. Annals of Tourism Research, 31(3): 657-668.

Brown, G., \& Gifford, R. (2001). Architects predict lay evaluations of large contemporary buildings: Whose conceptual properties? Journal of Environmental Psychology, 21(1): 93-99.

Carmona M, Heath, M. T., OC, T., \& Tiesdell, S. (2003). Public Spaces Urban Spaces. New York: The Architectural Press.

City Hall Kuala Lumpur. (2008). Draft Kuala Lumpur 2020 City Plan (Vol. 2). Kuala Lumpur: Percetakan Nasional Malaysia Berhad.

De Vaus, D. (2002). Surveys in Social Research. London: Routledge.
Fink, A. (2003). The Survey Handbook. USA, Thousand Oaks: Sage Publications.

Fowler, F. J. (1988). Survey Research Methods (Vol. 1). USA: Sage Publications.

Gehl, J. (2007). Public spaces for a changing public life. In C. Ward Thompson, \& P. Travlou (Eds.), Open space: People space (pp. 3-9). Abingdon, UK: Taylor and Francis.

Gehl, J., Gemzøe, L., \& Rogers, R. (2008). New City Spaces. Washington, DC: Island Press.

Gharai, F., \& Shokouhi, M. (2006). Enhancing the streetscape as the cultural heritage of the city (case study: Shemiran area, north of Tehran ). Paper presented at the Cultural Landscapes in the 21st Century, Forum UNESCO University and Heritage, University of Newcastle, UK.

Gjerde, M. (2011). Visual evaluation of urban streetscapes: How do public preferences reconcile with those held by experts? Journal of Urban Design International, 16(3), 153-161.

Gifford, R., Hine, D. W., Muller-Clemm, W., JR, D. J. R., \& Shaw, K. T. (2000). Decoding Modern Architecture: A Lens Model Approach for Understanding the Aesthetic Differences of Architects and Laypersons. Journal of Environment and Behavior, 32(2): 163-187.

Greene, S. (1992). City shape Communicating and Evaluating Community Design. Journal of the American Planning Association, 58(2), 177-189.

Hoinville, G., \& Jowell, R. (1978). Survey Research Practice. London: Heinemann Educational Books.

Imamoglu, Ç. (2000). Complexity, Preference and Familiarity: Architecture and Nonarchitecture Turkish Students' Assessments of Traditional and Modern House Façades. Journal of Environmental Psychology, 20(1), 5-16.

Ja'afar, N. H. (2006). Criteria of Successful Traditional Street in Attracting Visitor. Unpublished master's thesis, University Technology Malaysia, Malaysia.

Ja'afar, N. H., \& Usman, I. M. S. (2009). Physical and Transportation Elements of Traditional Street in Malaysia. European Journal of Social Sciences, 9(4), 669-676.

Ja'afar, N. H., Sulaiman, A. B., \& Shamsuddin, S. (2012). The contribution of landscape features on traditional streets in Malaysia. Procedia-Social and Behavioral Sciences, 50, 643-656.

Jacobs, J. (1961). The Death and Life of Great American Cities. New York: Random House. 
Johnson, B., \& Christensen, L. B. (2011). Educational Research: Quantitative, Qualitative, and Mixed Approaches. USA, Thousand Oaks: SAGE Publications.

Krier, R. (1977). Urban Space (Stradraum). London: Academy Editions.

Li, L. I., Yang, K. U. N., Shimokawa, T., Oyama, I., \& Kitamura, S. (2013). Investigation of factors affecting the evaluation of streetscapes in Japan and China. International Journal of Affective Engineering, 12(1), 1-10.

Lynch, K. (1960). The Image of the City. Cambridge: MIT Press.

Lynch, K. (1981). A theory of good urban form. Cambridge: MIT Press.

Mehta, V. (2007). Lively Streets: Determining Environmental Elements to Support Social Behavior. Journal of Planning Education and Research, 27(2), 165-187.

Mehta, V., \& Bosson, J. K. (2009). Third Places and the Social Life of Streets. Journal of Environment and Behavior, 42(6), 779805.

Moughtin, C. (2003). Urban Design: Street and Square. Oxford: Architectural Press.

Moughtin, C., Taner, O. C., \& Tiesdell, S. (1995). Urban design: ornament and decoration. Oxford; Boston, Mass: Architectural Press.

Myers, J. H. (2007). The historic character of buildings and districts. Retrieved 17, June, 2007, from http://architecture.about.com/library/blpres ervationbrief- siding02.htm.

Nasar, J. L. (1994). Urban design aesthetics: The evaluative qualities of building exteriors. Journal of Environment and Behavior, 26(3), 377-401.

Nasar, J. L., Stamps III, A. E., \& Hanyu, K. (2005). Form and function in public buildings. Journal of Environmental Psychology, 25(2), 159-165.

Nagaoka, A., Ogawa, R., \& Tsuchiya, T. (2013). Affective Engineering for Streetscape Analysis: Evaluation of Traditional Japanese Mud Walls Using a SelfOrganizing Map. In Systems, Man, and Cybernetics (SMC), $2013 \quad$ IEEE International Conference on (pp. 11321137) IEEE.

Nasar, J. L. (1989). Symbolic Meaning of House Styles. Journal of Environment and Behavior, 21(3), 235-257.

Naoi, T., Airey, D., Iijima, S. H., \& Niininen, O. (2006). Visitors evaluation of a historical district: Repertory grid analysis and laddering analysis with photographs. Journal of Tourism Management, 27(3), 420-436.
Oranratmanee, R., \& Sachakul, V. (2014). Streets as Public Spaces in Southeast Asia: Case Studies of Thai Pedestrian Streets. Journal of Urban Design, 19(2), 211-229.

Proshansky, H. M. (1978). The city and selfidentity. Journal of Environment and behavior, 10(2), 147-169.

Rapoport, A. (1990). History and precedent in environmental design. New York: Plenum.

Ryan, R. (2005). Exploring the Effects of Environmental Experience on Attachment to Urban Natural Areas. Journal of Environment and Behavior, 37(1), 3-42.

Shamsuddin, S. (1997). Identity Of Place A Case Study Of Kuantan town centre, Malaysia. Unpublished doctoral dissertation, University of Nottingham, England.

Shamsuddin, S., \& Ujang, N. (2008). Making places: The role of attachment in creating the sense of place for traditional streets in Malaysia. Journal of Habitat International, 32(3), 399-409.

Shamsuddin, S. (2011). Townscape Revisited: Unravelling the character of the historic townscape in Malaysia. Malaysia: Penerbit UTM Press.

Shamsuddin, S., Sulaiman, A. B., \& Amat, R. C. (2012). Urban Landscape Factors That Influenced the Character of George Town, Penang Unesco World Heritage Site. Procedia - Social and Behavioral Sciences, 50(July), 238-253.

Stamps III, A. E. (2004). Mystery, Complexity, Legibility and Coherence: A Metaanalysis. Journal of Environmental Psychology, 24(1), 1-16.

Tucker, C., Ostwald, M. J., Chalup, S. K., \& Marshall, J. (2004). A method for the visual analysis of the streetscape. Paper presented at 38th Annual Conference of the Architectural Science Association ANZAScA and the International Building Performance Simulation Association Australasia, University of Tasmania, School of Architecture, Australasia.

Ujang, N. (2008). Place Attachment Towards Shopping District in Kuala Lumpur City Centre. Unpublished doctoral dissertation, Universiti Putra Malaysia, Malaysia.

Ujang, N. (2012). Place Attachment and Continuity of Urban Place Identity. Procedia - Social and Behavioral Sciences, 49, 156-167.

Ujang, N., \& Dola, K. (2012). Linking activity and place attachment dimensions in enhancing the sense of place. International Journal of Sustainable Tropical Design Research and Practice, 2(1), 59-67.

Ujang, N., \& Shamsudin, S. (2012). The influence of legibility on attachment 
towards the Shopping Streets of Kuala Lumpur. Pertanika Journal of Social Sciences \& Humanities, 20(1), 81-92.

Wan Ismail, W. H., \& Shamsuddin, S. (2005).

The Old Shop-houses as Part of Malaysian Urban Heritage: The Current Dilemma. Paper presented at the 8th International Conference of The Asian Planning Schools Association, Grand Plaza ParkRoyal, Batu Ferringhi, Penang, Malaysia. 